Int. J. Curr. Res. Med. Sci. (2017). 3(4): 73-76

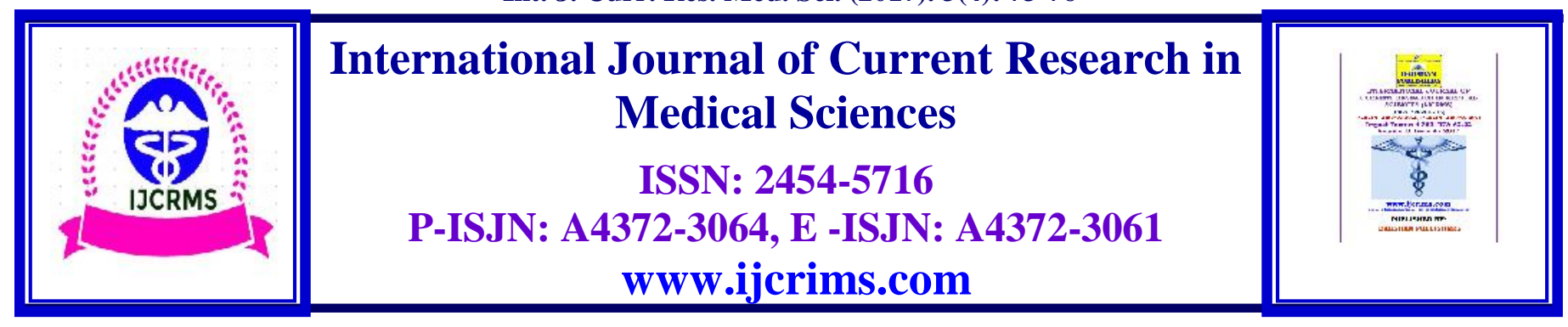

Update Article

Volume 3, Issue 4 -2017

DOI: http://dx.doi.org/10.22192/ijcrms.2017.03.04.011

\title{
Recent Advances in Management of Aluminium Phosphide Poisoning
}

\author{
N.S Neki", Gagandeep Singh Shergill ${ }^{* *}$, Amritpal Singh ${ }^{* * * * * * * * * *}$, Amanpreet Kaur:****, \\ Sharique Nizami*****, Taranjit Singh ${ }^{* * * * * *}$, Jatinderpal Singh Pannu \\ "Professor, "*Junior Resident, ${ }^{* * *}$ Senior Resident, Department of Medicine, \\ Govt. Medical college and Guru Nanak Dev Hospital, Amritsar, India \\ ${ }^{* * * * *}$ Consultant Gynaecologist, Civil Hospital, Fatehgarh Sahib, Punjab \\ ****** Senior Resident, Department of Surgery, Mata Gujari Memorial Medical College and LSK hospital, \\ Kishanganj, Bihar, India. \\ ${ }^{* * * * * * *}$ Registrar, Medical Oncology \& Haematology, Artemis Hospital, Gurgaon, Haryana \\ ********* Medical Officer, PCMS-1, distt. Taran Taran, Punjab \\ *Corresponding author: drneki123@gmail.com
}

\section{Abstract}

Aluminium phosphide (AIP), commonly known as celphos is a household name in villages of Punjab. This cheap solid fumigant and a highly toxic pesticide is commonly used for grain preservation. The post "green revolution" era saw alarmingly increased mortality by consumption of celphos for suicidal intent. Till date, there is no specific antidote for its intoxication and the poisoning carries extremely high mortality. The article will throw some light upon the recent advances that have been made regarding the management of acute aluminium sulphide poisoning (AAlPP).

Keywords: Aluminium phosphide poisoning; Celphos poisoning; AAlPP; ECMO; boric acid as an antidote to AAlPP

\section{Introduction}

AlP, a mitochondrial poison, exerts its toxicity due to deadly phosphine gas that is liberated when it reacts with water or hydrochloric acid in the stomach. Phosphine gas $\left(\mathrm{PH}_{3}\right)$, the active pesticide component of AlP, is rapidly absorbed by inhalation, ingestion, and skin or mucosal contacts. The mechanism of toxicity includes cellular hypoxia due to the effect on mitochondria, inhibition of cytochrome $\mathrm{C}$ oxidase and formation of highly reactive hydroxyl radicals. The signs and symptoms are nonspecific and instantaneous. The mortality ranges from $45 \%$ to $100 \%$.

\section{Discussion}

In Northern India, when it comes to choosing a poison for suicidal intent, celphos is perhaps the favourite choice of victims- way ahead of barbiturates, organophosphorus or copper sulphate $^{1}$. Upon contact with moisture in the environment, AlP undergoes a chemical reaction 
yielding phosphine gas. Phosphine inhibits cellular oxygen utilization and can induce lipid peroxidation. In the case of oral intake, the phosphine gas released is absorbed by the gastrointestinal tract with simple diffusion and is mainly excreted by the kidneys and lungs. Phosphine, like cyanide, inhibits mitochondrial cytochrome oxidase and cellular oxygen utilization $2,3,4$. It can rapidly perturb mitochondrial conformation and inhibit oxidative respiration by $70 \%$. This situation results a severe decrease in mitochondrial membrane potential ${ }^{3}$. AlP generates cellular superoxide and peroxide radicals, which trigger cellular damage by lipid peroxidation. The direct toxic effects of phosphine ${ }^{5}$ and phosphides ${ }^{6}$ on cardiac myocytes, fluid loss and adrenal gland can induce profound circulatory collapse. Death is usually a resultant of refractory myocardial depression, resistant hypotension, severe metabolic acidosis and acute respiratory distress syndrome.

Traditionally, the management of AAlPP is largely symptomatic as there is no specific antidote available. Gastric lavage with potassium permanganate $(1: 10,000)$ is done as it oxidizes $\mathrm{PH}_{3}$ to form non-toxic phosphate ${ }^{7}$. Activated charcoal (approximately $100 \mathrm{~g}$ ) given through a nasogastric tube to delay the absorption. Liquid paraffin, that accelerate the excretion of AlP and phosphine is often used ${ }^{8}$. For symptomatic relief from severe gastritis, antacids and proton pump blockers are employed. As AlPP is often associated with hypoglycaemia, correction of plasma glucose level with glucose containing fluids is done. Circulatory shock is dealt with 24 $\mathrm{hr}$ low dose dopamine (4-6 g/ $/ \mathrm{kg} / \mathrm{min})$ and intravenous fluids ${ }^{9}$. Hydrocortisone $200-400 \mathrm{mg}$ every 4-6 hr has been reported to be used with good results ${ }^{10}$. Patients who land up in ARDS require intensive care monitoring and mechanical ventilation. If systolic blood pressure is $>90 \mathrm{~mm}$ $\mathrm{Hg}$, Diuretics may be used to enhance excretion as the main route of elimination of phosphine is renal ${ }^{11}$. Arrhythmias are common and they are managed just as any other situation. Metabolic acidosis requires administration of intravenous sadium bicarbonate. Dialysis may be required for severe acidosis and acute renal failure.
Specific therapy and recent advances:

The clinical management of intoxication from AlP is mainly supportive. In one study, intravenous magnesium has shown significant improvement in indicators of oxidative stress and a lower incidence of mortality (20\%) in comparison to control subjects (44\% mortality) ${ }^{17}$. Oral administration of the anti-ischemic drug trimetazidine, which works through a metabolic mechanism of decreasing the production of oxygen-derived free radicals and stimulating the oxidative metabolism of glucose has been suggested to decrease mortality ${ }^{14,15}$. Administration of sorbitol solution (at a dose of 1$2 \mathrm{ml} / \mathrm{kg}$ ) as a cathartic and vegetable oils and liquid paraffin as inhibitor of phosphine release from the overdosed AlP has been suggested ${ }^{17}$. coconut oil has been shown to have a role in managing acute AlP poisoning even $6 \mathrm{~h}$ post ingestion ${ }^{18}$. Digoxin has been suggested for treatment of cardiogenic shock induced by acute AlP intoxication ${ }^{19}$.

Case reports and studies are available which suggest the treatment with various agents by various regimens with varying results. N-omeganitro-L-arginine methyl ester (L-NAME) ${ }^{20}, \mathrm{~N}-$ acetylcysteine ${ }^{20}$, hyperbaric oxygen ${ }^{21}, 25 \mathrm{Mg}^{2+}$ carrying nanoparticles ${ }^{22}$, intragastric irrigation with sweet almond oil $^{22}$, combination of vitamin $\mathrm{C}$ and methylene blue ${ }^{23}$, extensive gastric lavage with coconut oil and sodium bicarbonate solution with simultaneous aspiration ${ }^{24}$, intra-aortic balloon pump ${ }^{25}$, have all been used in isolation or in conjucnction with one another.

However, above all of them, Extracorporeal membrane oxygenation (ECMO) seems to hold the maximum promise regarding success management of this lethal poisoning. ECMO is a modified "heart-lung" machine to provide temporary cardiorespiratory support. Timely intervention with ECMO in patients with AlP poisoning-induced severe metabolic acidosis and refractory cardiogenic shock has shown significant improvement in overall survival in several trials and studies. Although EMCO is associated with significant complication rates of its own, it might come up as a promising 
"bridge therapy" in cases with intractable cardiorespiratory failure caused by AlP poisoning who are not responding to conventional treatment. $^{26,28,29}$

Soltani etal have purposed a very interesting hypothesis stating Boric acid as a "trapping agent" for deadly phosphine gas and hence, purposes it be a specific antidote. Boric acid is a non-toxic Lewis acid which efficiently traps $\mathrm{PH} 3$ gas. In this reaction, boric acid acts as a Lewis acid and phosphine acts as a Lewis base. The resulted polar reaction product which has $\mathrm{H}$ and $\mathrm{OH}$ groups can form hydrogen bonds with water molecules and hence can be excreted in urine by the body ${ }^{30}$. Though the idea appears very practical in theory, the hypothesis is yet to be tested for In vitro and in vivo studies.

\section{Conclusion}

Although there is no specific treatment for AAlPP as yet, various agents have been used with reasonable success. EMCO has proved to be a game changer. Boric acid could be the answer for the future.

\section{Financial Support and Sponsorship: Nil}

Conflicts of Interest: There are no conflicts of interest

\section{References}

1. Singh D, Dewan I, Pandey AN, Tyagi S. Spectrum of unnatural fatalities in the Chandigarh zone of north-west India - a 25 year autopsy study from a tertiary care hospital. Journal of Clinical Forensic Medicine 2003; 10(3):145-52

2. Rigobello MP, Scutari G, Boscolo R, Bindoli A. Induction of mitochondrial permeability transition by auranofin, a gold(I)-phosphine derivative. Br J Pharmacol 2002; 136:116268.

3. Valmas N, Zuryn S, Ebert PR. Mitochondrial uncouplers act synergistically with the fumigant phosphine to disrupt mitochondrial membrane potential and cause cell death. Toxicology 2008; 252:33-39.
4. Proudfoot AT. Aluminium and zinc phosphide poisoning. Clin Toxicol (Phila) 2009; 47:89100.

5. Almasieh M, Lieven CJ, Levin LA, Di Polo A. A cell-permeable phosphine-borane complex delays retinal ganglion cell death after axonal injury through activation of the pro-survival extracellular signal-regulated kinases 1/2 pathway. J Neurochem. 2011; 118:1075-86.

6. Hsu CH, Quistad GB, Casida JE. Phosphineinduced oxidative stress in Hepa 1c1c7 cells. Toxicol Sci 1998; 46:204-10.

7. Grover A, Bansal S. Aluminium phosphide poisoning. Manual of medical emergencies. New Delhi: M M Healthcare; 1997. 64:532-539.

8. Chugh SN, Arora V, Kaur S, Sood AK. Toxicity of exposed aluminium phosphide. J Assoc Phys Ind 1993; 41:569-70.

9. Chugh SN, Chugh K, Ram S, Malhotra KC. Electrocardiographic abnormalities in aluminium phosphide poisoning with special reference to its incidence, pathogenesis, mortality and histopathology. J Indian Med Assoc 1991; 89:32-35.

10. Gurjar M, Baronia AK, Azim A, Sharma K. Managing aluminum phosphide poisonings. J Emerg Trauma and Shock 2011; 4:378-84.

11. Shadnia S, Rahimi M, Pajoumand A, Rasouli MH, Abdollahi M. Successful treatment of acute aluminium phosphide poisoning: possible benefit of coconut oil. Hum Exp Toxicol 2005; 24:215-18.

12. Siwach SB, Jagdish K, Katyal VK, Dhall A, Bhardwaj G. Prognostic indices in aluminium phosphide poisoning observations on acidosis \& central venous pressure. J Assoc Physicians India. 1997;45:693-95.

13. International Programme on Chemical Safety. Environmental health criteria 73: phosphine and selected metal phosphides. Geneva: World Health Organization; $1998 . \quad$ Available from:http://www.who.int/ipcs/publications. Last visited 27/11/2016.

14. de Leiris J, Boucher F. Rationale for trimetazidine administration in myocardial ischaemia-reperfusion syndrome. Eur Heart J 1993; Suppl G:34-40. 
15. Lopaschuk GD. Treating ischemic heart disease by pharmacologically improving cardiac energy metabolism. Am J Cardiol 1998; 82:14K-17K.

16. Duenas A, Perez-Castrillon JL, Cobos MA, Herreros V. Treatment of the cardiovascular manifestations of phosphine poisoning with trimetazidine, a new antiischemic drug. Am J Emerg Med 1999; 17:219-20.

17. Siwach SB, Singh P, Ahlawat S, Dua A, Sharma D. Serum \& tissue magnesium content in patients of aluminium phosphide poisoning and critical evaluation of high dose magnesium sulphate therapy in reducing mortality. J Assoc Physicians India 1994; 42:107-10.

18. Goswami M, Bindal M, Sen P, Gupta SK, Avasthi R, Ram BK. Fat and oil inhibit phosphine release from aluminium phosphideits clinical implication. Indian J Exp Biol 1994; 32:647-49.

19. Mehrpour O, Farzaneh E, Abdollahi M. Successful treatment of aluminum phosphide poisoning with digoxin. Int J Pharmacol 2011; 7(7):761-64.

20. Azad A, Lall SB, Mittra S. Effect of Nacetylcysteine and LNAME on aluminium phosphide induced cardiovascular toxicity in rats. Acta Pharmacol Sin 2001; 22:298-304.

21. Saidi H, Shokraneh F, Ghafouri HB, et al. Effects of hyperbaric oxygenation on survival time of aluminum phosphide intoxicated rats. J Res Med Sci 2011; 16:1306-12.

22. Saidi H, Shojaie S. Effect of sweet almond oil on survival rate and plasma cholinesterase activity of aluminum phosphideintoxicated rats. Hum Exp Toxicol 2011; 31(5):518-22.

23. Soltaninejad K, Nelson LS, Khodakarim N, et al. Unusual complication of aluminum phosphide poisoning: development of hemolysis and methemoglobinemia and its successful treatment. Ind J Crit Care Med 2011; 15:117-19.

24. Bajwa SJ, Bajwa Kaur SK, Kaur J. Management of celphos poisoning with a novel intervention: a ray of hope in the darkest of clouds. Anesth Essays Res 2010; $4: 20-4$.
25. Siddaiah L, Adhyapak S, Jaydev S. Intraaortic balloon pump in toxic myocarditis due to aluminum phosphide poisoning. $\mathrm{J}$ Med Toxicol 2009; 5:80-3.

26. Mittra S, Peshin SS, Lall SB. Cholinesterase inhibition by aluminium phosphide poisoning in rats and effects of atropine and pralidoxime chloride. Acta Pharmacol Sin 2001; 22:37-9.

27. Hassanian-Moghaddam H, Zamani N, Rahimi M, Hajesmaeili M, Taherkhani M, Sadeghi R. Successful Treatment of Aluminium Phosphide Poisoning by Extracorporeal Membrane Oxygenation. Basic Clin Pharmacol Toxicol 2016 Mar; 118(3):243-6.

28. de Lange DW, Sikma MA, Meulenbelt. Extracorporeal membrane oxygenation in the treatment of poisoned patients. J Clin Toxicol (Phila) 2013 Jun; 51(5):385-93.

29. Mohan B, Singh B, Gupta V, Ralhan S, Gupta $\mathrm{D}$, Puri S, et al. Outcome of patients supported by extracorporeal membrane oxygenation for aluminum phosphide poisoning: An observational study. Indian Heart J 2016 MayJun; 68(3):295-301.

30. Soltani M, Shetab-Boushehri SF, Mohammadi $\mathrm{H}$, Shetab-Boushehri SV. Proposing boric acid as an antidote for aluminium phosphide poisoning by investigation of the chemical reaction between boric acid and phosphine. $\mathrm{J}$ Med Hypotheses and Ideas 2013; 7:21-4.

\begin{tabular}{|c|l|}
\hline \multicolumn{2}{|c|}{ Access this Article in Online } \\
\hline Quick Response Code & Website: \\
\cline { 1 - 1 } & Www.ijcrims.com \\
\cline { 1 - 2 } & \\
\hline
\end{tabular}

How to cite this article:

N.S Neki, Gagandeep Singh Shergill, Amritpal Singh, Amanpreet Kaur, Sharique Nizami, Taranjit Singh, Jatinderpal Singh Pannu. (2017). Recent Advances in Management of Aluminium Phosphide Poisoning. Int. J. Curr. Res. Med. Sci. 3(4): 73-76.

DOI:http://dx.doi.org/10.22192/ijcrms.2017.03.04.011 